\title{
Rевенсн АвтіскE: Marketing channels, cost, margins and price spread of Bt cotton in Bharuch district of South Gujarat
}

\section{J. M. Khichadiya and J. J. Makadia}

Article Chronicle :

Received :

15.02.2020;

Revised:

04.10.2020;

Accepted :

23..10.2020

Key Words :

Bt cotton, Marketing channel, Marketing cost, Marketing margin, Price spread

JEL Codes: M31, Z33, L11

Author for correspondence :

\section{J.M. Khichadiya} Department of

Agricultural Economics, N. M. College of Agriculture, Navsari Agricultural University,

Navsari (Gujarat) India

Email: jkhichadiya11@ gmail.com

See end of the article for

authors' affiliations
SUMMARY : This study was conducted for estimation of marketing cost, marketing margin and price spread through different marketing channels of $B t$ cotton in Bharuch district of South Gujarat region. Two major marketing channels were identified for the Bt cotton i.e., Channel-I: Producer $\rightarrow$ CCI (Cotton Corporation of India) and Channel-II: Producer $\rightarrow$ Commission Agent $\rightarrow$ Ginner $\rightarrow$ Consumer. The producer could secure about 88.24 and 83.00 per cent of consumer's rupee in channel-I and channel-II of Bharuch district, respectively. Thus, the channel-I in Bharuch district was found to be more efficient as compared to other channels. The major problems faced by the farmers in production of Bt cotton found that, non-availability of agricultural labour during peak seasons, lack of availability of recommended plant protection chemicals, high incidence of attack from bollworms, non-availability of quality seeds of Bt cotton in time, lack of availability and high cost of recommended fertilizers, growth of weeds, lack of irrigation facilities.

How to cite this article : Khichadiya, J.M. and Makadia, J.J. (2020). Marketing channels, cost, margins and price spread of Bt cotton in Bharuch district of South Gujarat. Agric. Update, 15(4): 391-396; DOI : 10.15740/ HAS/AU/15.4/391-396. Copyright@2020: Hind Agri-Horticultural Society. 